\title{
REFORMED ORTHODOXY ON IMPUTATION. ACTIVE AND PASSIVE JUSTIFICATION
}

\author{
JOHN V. FESKO*
}

Westminster Seminary California

\begin{abstract}
The doctrine of imputation is common to Early Modern Lutheran and Reformed theology, but Reformed orthodox theologians employed the distinction between the active and passive justification of the believer. Active justification is the objective imputation of Christ's righteousness and passive justification is the subjective reception of the same. This distinction is a unique contribution in Reformed orthodox dogmatics and was used in polemics against Roman Catholic, Arminian, and Socinian theologians. This essay also compares Reformed orthodox formulations with Lutheran orthodox understandings of how they preserved the extra nos of Christ's righteousness in justification. The Reformed orthodox employed the active-passive justification distinction in conjunction with the decree and the doctrine of the covenant of redemption, whereas the Lutheran orthodox logically placed justification first in the order of salvation. Both groups maintain the extra nos of Christ's imputed righteousness but do so in different ways.
\end{abstract}

KEY WORDS: imputation, active justification, passive justification, justification, union with Christ.

\section{Introduction}

The doctrine of the imputed righteousness of Christ is a hallmark teaching of the Reformed tradition and appears in numerous Reformed confessions and catechisms. Reformation era (1517-65) confessions and catechisms that affirm the doctrine of imputed righteousness include the Tetrapolitan Confession (1530), III; Forty-Two Articles (1553), XI; French Confession (1559), XVIXX; Belgic Confession (1561), XXII-XXIII; Heidelberg Catechism, qq. 60-61; and Second Helvetic Confession (1566), XV (Pelikan and Hotchkiss 2003). But the doctrine of imputed righteousness is not unique to the Reformed tradition, as the Lutheran tradition also affirms it (Kolb and Wengert 2000).

Where the doctrine of imputed righteousness takes on a unique form, however, is in the hands of Reformed orthodox theologians of the seventeenth century in terms of iustificatio activa et passiva ('active and passive justification'). Alternate terms for this distinction are iustificatio objectiva et subjectiva

* JOHN V. FESKO (PhD 1999, University of Aberdeen) is professor of systematic and historical theology as well as academic dean at Westminster Seminary California, Escondido, California, United States of America. Email: jvfesko@wscal.edu. 
('objective and subjective justification') (Muller 1985: 162-63). In short, active justification denotes the objective work of Christ and the imputation of his righteousness to the elect. Passive justification is the subjective reception of Christ's righteousness by faith alone. Active justification logically precedes passive justification; moreover, active justification logically precedes regeneration and faith in the ordo salutis ('order of salvation'). The active-passive distinction is unique to the Reformed orthodox doctrine of imputation. But to date, there is very little historical research on this aspect of the Reformed doctrine of imputation (Beeke and Jones 2012: 133-48; Bavinck 2003-08: IV:219-23; Berkhof 1996: 517; Tipton 2013: 1-12).

Therefore, in this essay I treat the active-passive distinction to highlight this unique element of the Reformed doctrine of imputation. First, I illuminate the historical-theological context that accounts for the rise of the distinction. Second, I explain the distinction's basic tenets and its context within the cradle of Reformed covenant theology by examining early (1565-ca.1640) and high orthodox (ca. 1640-1700) formulations. Third, for the sake of providing a thicker account of this unique aspect of the Reformed doctrine of imputation, I compare and contrast the active-passive distinction with some Lutheran orthodox formulations. While Lutheran and Reformed orthodox theologians shared the doctrine of imputed righteousness and were equally concerned to protect its alien nature, the extra nos of imputation, Lutherans addressed these concerns in a different manner than their Reformed counterparts. They did not employ the doctrine of the covenants, nor did they agree with Reformed theologians on the doctrine of predestination. Hence, they resorted to fine-toothed distinctions regarding the ordo salutis. Fourth, and last, I conclude the essay with some general observations about the historical-theological significance of the uniqueness of the Reformed doctrine of imputed righteousness.

\section{Historical Reformation Origins}

The precise origin of the active-passive distinction is beyond the scope of this essay. What is more important is establishing the historical-theological context that gave rise to the distinction. There are three likely reasons that account for the idea's development: the Tridentine rejection of the doctrine of imputation, the Osiander controversy, and the rise of Remonstrant theology.

The Council of Trent. From the earliest days of the Reformation, theologians spoke of justification by faith alone (sola fide), which was the means by which they protected the idea of the imputation of the alien righteousness of Christ. Roman Catholic theologians were well aware of this and called the Council of Trent to respond. There were some Roman Catholic theologians, such as bishops Reginald Pole (1500-58) and Girolamo Seripando (1493-1563), who 
were sympathetic to the teaching of Martin Luther (1483-1546). Nevertheless, Diego Layñez (1512-65), a Spanish Jesuit, stepped forward and from some scribbled notes and memory, offered a three-hour speech against imputation. Despite the sympathies for Luther's doctrine among some of the delegates, Layñez's speech was influential and undoubtedly led to the unanimous approval of the decree on justification (O'Malley 2013: 104-13; Fichter 1944: 61-65; Maxcey 1979: 269).

Layñez offered numerous reasons as to why he believed the doctrine of imputed righteousness was erroneous (Layñez 1886: 153-92). But at the core of his concerns was the idea that imputation left little room, if at all, for the believer's good works or merits: 'Where we find imputation, we do not find, properly speaking, merit' (Layñez 1886: 167). This comment represents one of the chief fulcrums in the debates over justification between the Roman Catholics and the Reformed-Rome taught justification by faith working through love and the Reformed, along with the Lutherans, believed in justification sola fide (Calvin 2009: 114-17, 128). The Protestant reformers were adamant about protecting the extra nos of justification and recognizing that its legal ground was imputed, not inherent, righteousness.

The Osiander Controversy. Another pressure point against the doctrine of imputed righteousness arose with the controversy surrounding the views of $\mathrm{Lu}$ theran theologian, Andreas Osiander (1498-1552). In contrast to Luther and Philip Melanchthon (1497-1560), who both believed that justification was a forensic declaration that rested upon Christ's imputed righteousness, Osiander maintained that believers instead shared in the essential righteousness of Christ's divine nature by virtue of personal indwelling (cf. Osiander 1994: 422-47; Mattes 264-73). Osiander's view was justification by indwelled righteousness, or by union with Christ, rather than imputed righteousness received by faith alone. To say the least, Osiander threw a firebomb onto the theological playground of Europe that provoked a heated and sustained refutation from both Lutheran and Reformed theologians (Wengert 2013: 6387; Wengert 2012; Arand, Kolb, and Nestingen 2012: 217-26).

Theologians from both camps were eager to preserve the extra nos of imputation and at the same time affirm the doctrine of union with Christ. Melanchthon, for example, writes: 'We clearly affirm the presence or indwelling of God in the reborn'. But he nevertheless carefully explains the relationship between indwelling and justification: 'Although God dwelt in Moses, Elijah, David, Isaiah, Daniel, Peter, and Paul, nevertheless none of them claimed to be righteous before God on account of this indwelling or the effecting of their renewal but on account of the obedience of the Mediator and his gracious intercession, since, in this life, the remnants of sin were still in them' (Me- 
lanchthon 2002: 208-09; Melanchthon 1841: 579-87, esp. 582-83). John Calvin (1509-64) responded in similar fashion in a section in his 1559 edition of the Institutes that he specifically added to refute Osiander. Calvin insisted that believers had to turn away from their own works and only look to God's mercy in Christ for their righteousness: 'This is the experience of faith... that with Christ's righteousness interceding and forgiveness of sins accomplished [the sinner] is justified. And although regenerated by the Spirit of God, he ponders the everlasting righteousness laid up for him not in the good works to which he inclines but in the sole righteousness of Christ' (Calvin 1960: III.xi.16; Calvin 1559). Calvin, like Melanchthon, acknowledges divine indwelling, but nevertheless rests justification upon an alien righteousness outside of the believer.

The Arminius Controversy. The third pressure point that led to the creation and use of the active-passive distinction was the Reformed tradition's engagement with Remonstrant theology. People usually associate the Arminian controversy with Jacob Arminius (1560-1609) and the doctrine of predestination and the question of the extent of Christ's satisfaction. For whom did Christ die? These associations are correct but do not represent every debated doctrinal issue. Some Reformed theologians, such as Sibbrandus Lubbertus (ca. 1555-1625) and Francisus Gomarus (1563-1641), also expressed concerns over Arminius's doctrine of justification (Goudriaan 2010: 155-78). Briefly, in contrast to the Reformed, Arminius believed that justification rested upon the believer's faith rather than Christ's imputed righteousness. For the Reformed, justification did not rest upon faith; faith is the instrument of justification, not its legal basis (Fesko 2014: 1-21).

Summary. In all three cases, theologians sought to locate the basis for justification within the believer. Rome based justification upon Christ's merit and the believer's good works by faith working through love. Osiander based justification upon the essential righteousness of Christ to which believers had access by virtue of their union with Christ and his indwelling presence. And Arminius based justification upon faith-God looked upon the believer's faith as if it were righteousness. In each of these controversies, Reformed theologians rejected attempts to locate the basis of justification in the believer and preserved the extra nos of justification-the alien imputed righteousness of Christ received by faith alone.

Early Reformed Orthodoxy (1565-ca. 1640)

As the Reformed church engaged critics of the doctrine of imputed righteousness, they also refined the presentation of their own doctrinal formula- 
tions. Among the many developments and refinements was the greater integration of covenant theology into Reformed theological systems (Muller 2007: 11-65; Fesko 2015). It is particularly the doctrine of the pactum salutis, the eternal intra-trinitarian covenant to plan and execute the redemption of the elect that was the context in which Reformed orthodox theologians moved the doctrine of imputation to ensure that Christ's righteousness served as the sole basis for the believer's justification. But we must first explore the earliest uses of the distinction before we examine some of the more developed formulations.

In what is perhaps one of the earliest uses of the active-passive distinction, Lucas Trelcatius, Jr. (1573-1607) dissects the doctrine of justification by explaining what God does and what people do. Throughout his locus on justification, Trelcatius distinguishes between the two sides of the doctrine, 'Actively, in respect of God, who iustifyeth; or Passively, in respect of man, who is iustified' (Trelcatius 1610: 227; Trelcatius 1604: 79). In context, Trelcatius engaged 'the Popelings' (Pontificiis) who believed that an infused disposition of righteousness was necessary for justification (Trelcatius 1610: 228).

Trelcatius countered the idea of inherent righteousness through the concept of active justification, for which Christ and his merit (his active and passive obedience) is the impulsive cause. Passive justification, on the other hand, is wholly instrumental and receptive (Trelcatius 1610: 229). Although he does not mention Osiander by name, Trelcatius nevertheless excludes any notion of Christ's essential or divine righteousness as the foundation of active justification. Rather, Christ's 'perfect obedience, performed to the Father, both by satisfaction for sin, and by fulfilling of the Law', constitutes the legal ground for active justification (Trelcatius 1610: 231).

Trelcatius relates Christ's imputed righteousness to his office as surety, by which Christ was bound by a 'voluntary dispensation, to undergoe, and performe those things'. Christ's role as surety ensured he would pay the debt of sin on behalf of the elect (Trelcatius 1610: 232-33). But Trelcatius did not characterize this legal imputation in terms of a cold mathematical exchange of righteousness for sin. Trelcatius explains: 'The forme of Iustification, taken actively, is a free imputation of Christ's actuall righteousnesse, whereby the merits and obedience of Christ are applied unto us by virtue of that most strait communion, whereby he is in us, and we in him' (Trelcatius 1610: 234). The Reformed did not object to relating justification to union with Christ, but unlike Osiander, they insisted that justification rests upon Christ's imputed righteousness, not inherent righteousness. So Trelcatius wraps active justification and the imputation of Christ's righteousness in the doctrine of union with Christ, but he carefully stipulates that imputed righteousness is neither a habitual possession nor the substance of Christ, nor an inherent 
quality in the believer (Trelcatius 1610: 235). With this particular qualification Trelcatius affirms union with Christ but rejects the views of Osiander and the Roman Catholic Church, though he later mentions Robert Bellarmine (1542-1641) as a specific opponent (Trelcatius 1610: 244; cf. Bellarmine 1610: I.xiii-xix, cols. 747-72). In his mind, righteousness is a gift and is technically 'out of us' (extra nos), even though we receive it through union with Christ (Trelcatius 1610: 236; Trelcatius 1604: 82).

Trelcatius may have been one of the first to employ the active-passive distinction but he was soon joined by other theologians. Johannes Wollebius (1589-1629) published his Christianae Theologiae Compendium in 1626, and he uses the distinction in virtually the same manner. He too, like Trelcatius, was concerned about Roman Catholic teaching and sought to distinguish the active and passive elements of justification. Understood actively, both the matter and form of justification is the 'imputation of the entire satisfaction of Christ'. Passively considered, the matter 'is man who is wretched in himself, but nevertheless chosen by God, called, and given faith'. Wollebius makes an important qualification, however, that will appear in other theologians, especially Lutheran Orthodox formulations. Namely, 'Therefore, although calling is prior to faith and faith to justification, in the nature of the matter [natura sit prior], yet they do not take place at different times. As soon as one is effectively called, he is given faith and justified by faith' (Wollebius 1965: I.xxx.11-12; Wollebius 1633: 249). Wollebius distinguishes the different elements of redemption (calling, faith, and justification) but recognizes that they all occur simultaneously. When he invokes the term natura, he employs a medieval distinction regarding the ordo naturae ('order of nature'), which allowed theologians logically to order and prioritize aspects of complex doctrines. More will be said about this below ( $\$ 4)$. Nevertheless, another point to note is that, though Wollebius distinguishes the different elements of redemption, he not only recognizes the simultaneity of their application but also that they all come through union with Christ (Wollebius 1965: I.xxx.13).

Around the same time that Wollebius published his Compendium, William Ames (1576-1633) published his Medulla S. S. Theologiae (1630). Ames does not employ the active-passive distinction, but he argues that there are three doctrinal pivot points for justification. He locates justification in the decree of God, in Christ's personal justification through his resurrection from the dead, and in the declaration when a person makes a profession of faith. There is a sense in which the elect are justified before they make a profession of faith, though Ames carefully stipulates that believers are 'in actuality' (virtualiter pronunciatur) justified when 'faith is born' (fide ingenerata exurgit) (Ames 1968: I.xxvii.9; Ames 1630). Ames is not unique as a similar construction appears in Girolamo Zanchi (1519-90) (Zanchi 1590: IV.ii.7). While it may not be immediately evident, there are important substantive connections between 
the formulations of Trelcatius and Ames. Trelcatius acknowledged that Christ's role as surety positioned his merit as the sole legal basis for justification, and Ames similarly recognized that justification first existed in the decree. In other words, both theologians coordinate justification, especially imputation, in Christ's appointment as surety in the decree.

\section{High Reformed Orthodoxy (ca. 1640-1700)}

Westminster and Savoy

The coordination of the decree, Christology, and justification continued to develop in the years immediately following the publication of these three Early Orthodox works through the labors of the Westminster Assembly. The Westminster divines were keen on protecting the integrity of the doctrine of justification from a number of different errors, and they spell them out in the Westminster Confession of Faith (1648). They preclude the views of Roman Catholicism, Osiander, and Arminius when they state that justification is not the infusion of righteousness, nor 'anything wrought in them, or done by them... nor by imputing faith it self, the act of beleeving, or any other evangelicall obedience, to them, as their righteousnesse, but, by imputing the obedience and satisfaction of Christ unto them' (Westminster 1648: XI.i). But the divines were also concerned to proscribe another problematic doctrine, namely, justification from eternity. In the ongoing efforts to protect the extra nos of imputed righteousness and the monergistic nature of justification, some theologians, such as William Twisse (1578-1646), prolocutor of the Westminster Assembly, argued that God fully justified the elect in eternitythat justification was an immanent act of the triune God, which protected the doctrine from Neonomian claims that good works played some role in the believer's justification (Twisse 1632: 197). When people made a profession of faith they merely became aware of their already-justified status. Theologians who promoted justification from eternity employed the in foro Dei ('in the court of God') and the in foro conscientiae ('in the court of conscience') distinction to account for their view. In other words, God justified the elect in eternity in foro $D e i$, but the elect discovered their justified status by faith in foro conscientiae (Boersma 2004: 80-87). In this type of formulation, justification precedes all of the other benefits of redemption; a completed justification is first in the ordo salutis.

The divines were well aware of such views and rejected them (Van Dixhoorn 2009: 395-418). They write: 'God did, from all eternity, decree to justifie all the elect, and Christ did, in the fullnesse of time, die for their sins, and rise again for their justification: neverthelesse, they are not justified, until the holy Spirit doth, in due time, actually apply Christ unto them' (XI.iv). Echoing the earlier formulations of Ames and Zanchi, the divines do not em- 
ploy the active-passive distinction, but they do recognize that justification exists in the decree. The elect, however, are not actually justified until they make a profession of faith. Moreover, in concert with the earlier formulations of Trelcatius, Wollebius, and Ames, the divines coordinate the decree, christology, and justification: 'It pleased God, in His eternall purpose, to choose and ordain the Lord Jesus, His only begotten Son, to be the Mediatour between God and Man; the Prophet, Priest, and King, the Head, and Saviour of his Church, the Heir of all things, and Judge of the World: Unto whom He did from all eternity give a People, to be his Seed, and to be by him in time Redeemed, Called, Justified, Sanctified, and Glorified' (VIII.i). The divines link the decree, Christ's role as mediator, and justification, but rest it upon the decree-execution distinction.

Very shortly after the Westminster Assembly, congregational theologians adopted a modified version of the Westminster Confession, the Savoy Declaration (1658). First, under the guidance of John Owen (1616-83) and Thomas Goodwin (1600-80), Savoy modifies Westminster Confession XI.iv, noted by the italicized word: 'God did from all eternity decree to justifie all the Elect... Nevertheless, they are not justified personally, until the holy Spirit doth in due time actually apply Christ unto them' (Savoy 1659: XI.iv). The Savoy divines inserted the word personally to emphasize that justification objectively exists prior and outside of the elect but the elect must individually lay hold of it by faith. This construction echoes Ames's earlier formulations and finds expression in Goodwin's tria momenta of justification: (1) the decreed justification in the covenant of redemption, (2) the justification of Christ in history, and (3) the actual justification by faith of the elect (Jones 2010: 230-38).

The second key modification comes in Savoy VIII.i, indicated by italicized print: 'It pleased God in his eternal purpose, to chuse and ordain the Lord Jesus his onely begotten Son, according to the Covenant made between them both, to be the Mediator between God and Man... unto whom he did from all eternity give a people to be his seed, and to be by him in time redeemed, called, justified, sanctified, and glorified'. In contrast to Westminster, the Savoy divines explicitly included the doctrine of the covenant of redemption. In other words, Christ's appointment as mediator and surety was the context in which the triune God decreed the justification of the elect. These developments (the coordination of the decree, Christology, justification, and covenant) all set the stage for the most developed arguments for the active-passive distinction, which flower in the period of High Orthodoxy.

High Orthodox Theologians

A significant number of High Orthodox theologians employ the active-passive distinction including Bartholomäus Keckermann (ca. 1572-1608), Mar- 
cus Wendelin (1584-1652), Johannes Maccovius (1588-1644), Anthony Tuckney (1599-1670), Samuel Maresius (1599-1673), Samuel Rutherford (160061), John Brown of Wamphray (ca. 1610-79), Johannes Hoornbeck (161766), Andreas Essenius (1618-77), Francis Turretin (1623-87), Christoph Wittich (1625-87), Petrus Van Mastricht (1630-1706), Johannes Heidegger (1633-98), Wilhelmus á Brakel (1635-1711), Leonard Rijssen (1636-1700), Herman Witsius (1636-1708), Melchior Leydekker (1642-1721), and Johannes Marckius (1656-1731) (Fesko 2012: 352). In some cases, these advocates simply invoke the distinction without much explanation-there is no immediate stated concern about a specific theological error or opponent (Maccovius 1656: 124-25; Brown 1695: 348-49; Rijssen 1695: 145-46, 159; and Tuckney 1649: 73). In other cases, theologians have specific erroneous views in the crosshairs. Maresius and Heidegger target Roman Catholic doctrine, specifically Tridentine twofold justification (Maresius 1659: 453; Heidegger 1690: 541). Rutherford raises the distinction in his refutation of Roman Catholic and Arminian views (Rutherford 1636: 43). Marckius targets the views of Roman Catholics, Arminians, and Schismatics (Marckius 1749: 461-62). Wittich brings the distinction to bear against Arminians (Wittich 1675: 100-01). À Brakel raises the distinction in his refutation of justification from eternity (À Brakel 1993: II:376-78). Turretin opens his question on justification by faith with the distinction to respond to the errors of Socinians, Remonstrants, and Romanists (Turretin 1992-97: XVI.vii.1). And Witsius invokes the distinction to respond to Arminius's doctrine of faith (Witsius 1990: II.vii.16). There is therefore no single target in view but rather Reformed orthodox theologians employ the distinction for different reasons and to respond to various (in their eyes) erroneous views.

\section{Herman Witsius}

One theologian who addresses the subject in great detail is Witsius, and thus his understanding of the distinction deserves examination. Witsius employs the distinction in two separate loci in his system, under his treatments of the satisfaction of Christ and justification. In his treatment of Christ's satisfaction, Witsius responds to Arminius's doctrine of faith, namely, that faith is the ground of our acceptance before the divine bar. Witsius objects: 'Faith is not considered as impetrating, but as applying the impetrated remission' (Witsius 1990: II.vii.16; Witsius 1685). Witsius explains that the righteousness that justifies does not belong to the believer but to Christ, as it is his obedience: 'This righteousness of Christ, was really his, as it was wrought out by him; and it is ours, as it was wrought out for us: therefore, in a sound sense, even ours before faith, being the meritorious cause of that grace which is effectual to 
produce faith in us' (Witsius 1990: II.vii.16). Witsius describes Christ's righteousness as objective and prior to the regeneration of and Christ's actual union with the elect.

Witsius goes on to distinguish the difference between right (ius) and possession (possessio) (cf. Luther 1957: 333-77, esp. 352-54; Oberman 1992: 121). Prior to their conversion the elect have right to the righteousness of Christ but they do not possess it by faith. At this point Witsius introduces the activepassive distinction, terms that are 'well known' (Witsius 1990: II.vii.16). Active justification 'is that sentence of God, by which he declares his having received satisfaction from Christ, and pronounces that all the elect are made free from guilt and obligation to punishment, even before their faith, so far as never to exact of them any payment'. By contrast, passive justification 'is the acknowledgment and sense of that most sweet sentence, intimated to the conscience by the Holy Spirit, and fiducially apprehended by each of the elect'. In Witsius's mind, this distinction answers 'the cavils of Arminius' (Witsius 1990: II.vii.16).

There are several noteworthy observations about Witsius's use of the active-passive distinction. First, we must recognize that his treatment of Christ's satisfaction falls under the broader context of the pactum salutis, the eternal covenant between the Father and Son. His treatment of the pactum opens book II on the covenant of grace (Witsius 1990: II.ii.1-16). Part of the stipulations of the pactum is that the Son, as mediator and covenant surety, would render perfect obedience to the Father and suffer the penalty of the law on behalf of the elect (Witsius 1990: II.iii.12). Within the pactum Christ's obedience bears the relationship of both antecedent to consequent and of merit to reward-his obedience is the cause and fulfilled condition that secures the reward of life (Witsius II.iii.32). God imputes Christ's work as covenant surety to the elect. Witsius writes: 'This is the first effect of Christ's suretiship, the declaration of that counsel of God, by which he had purposed to justify the ungodly; and not to impute sin to those who are inserted as heirs in the testament' (Witsius 1990: III.viii.52).

Second, Witsius couches the active-passive distinction in the midst of several other distinctions in his doctrine of justification. Witsius identifies articulus ('articles') of justification. He distinguishes between general and particular justification-general justification is the absolution that God declares over the elect 'in general collected into one mystical body'. The first article of general justification occurred immediately on the heels of the fall, when Christ's suretiship formally began; the second article of general justification is when Christ offered himself in his sacrificial death on the cross (Witsius 1990: III.viii.52).

Within particular justification Witsius identifies five articles. The first is when the elect are regenerated and united to Christ; they pass from a state 
of condemnation and wrath to grace and favor. Upon the person's profession of faith God declares in foro coeli ('in the court of heaven') that he is no longer in a state of wrath. This can occur and yet a person might still be ignorant of his justified status. In the second article of particular justification God announces the verdict to the person's conscience. The believer knows, feels, and experiences the forgiveness of sins. The third article of particular justification is when the person who has been actively and passively justified (active et passive justificatus) enters into communion and mutual friendship with God (amicitae consortium). The fourth article is when, immediately upon death, God assigns to the soul upon its departure from the body an eternal mansion.

The fifth and final article is at the final judgment when the elect will be publically justified, which Witsius denominates universal justification (justificatio universalis) (Witsius 1990: III.viii.59-63). But lest his readers misunderstand, Witsius stipulates that this public justification differs from the believer's justification by faith, which he calls the justificatio impii, or justification of the ungodly (Romans 4:5) (Witsius 1990: III.viii.64). The legal ground of the universal justification, which is a vindication before the world, is inherent righteousness, which comes by the Spirit of sanctification (Witsius 1990: III.viii.65). The legal ground of particular justification, however, is 'no other than the righteousness of Christ the Lord, communicated to them according to the free decree of election, which is succeeded by adoption, which gives them a right to take possession of inheritance' (Witsius 1990: III.viii.66). Although Witsius applies the term justification to the events surrounding the believer's assessment at the final judgment, the grounds are different and so are the consequents-universal justification merely confirms the piety of the believer whereas particular justification, grounded upon active justification (the imputed righteousness of Christ) originating in the pactum salutis, secures his eternal inheritance (Witsius III.viii.65-66).

Witsius heaps distinction upon distinction to dizzying heights, but he nevertheless preserves the extra nos of justification through the active-passive distinction. The following chart illustrates this point:

\begin{tabular}{|c|c|c|}
\hline & General Justification & Particular Justification \\
\hline \multirow[t]{2}{*}{ Articles } & $\begin{array}{l}\text { 1. Sentence of absolution over the } \\
\text { elect-the mystical body }\end{array}$ & $\begin{array}{l}\text { 1. Declared in the court of } \\
\text { heaven to have passed from con- } \\
\text { demnation to grace }\end{array}$ \\
\hline & $\begin{array}{l}\text { 2. Declaration of satisfaction was } \\
\text { made by Christ's death }\end{array}$ & $\begin{array}{l}\text { 2. Sentence of God in the con- } \\
\text { science }\end{array}$ \\
\hline
\end{tabular}




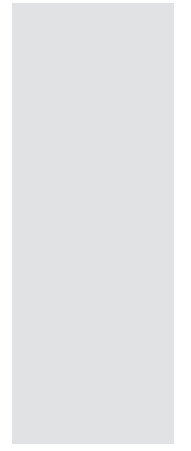

\author{
3. Once actively and passively \\ justified entering communion \\ and participation with God. \\ 4. Upon death the soul is as- \\ signed a mansion in heaven \\ 5. Universal justification based \\ upon Spirit-produced sanctifica- \\ tion as evidence of personal pi- \\ ety
}

Witsius, like other High Orthodox theologians simply wanted to delineate the different elements within the doctrine of justification. In this regard, theologians like Samuel Maresius and Leonard Rijssen observe that the activepassive distinction does not denote a degree or kind of justification but merely highlights the à quo $\Xi$ ad quem ('by whom and to whom') of the doctrine (Maresius 1659: 453; Rijssen 1695: 159). God imputes Christ's righteousness and believers receive it. The active-passive distinction parallels another common distinction: the impetration and application of redemption. Moreover, given that High Orthodox theologians such as Witsius nestle active justification high in the eternal nest of the pactum salutis and decree of God, creabiles homines ('creatable men') who do not, as of yet, have existence cannot somehow wrest or move the legal basis for justification away from Christ.

We can now move on to a comparison of this Reformed elaboration of the doctrine of justification with the way in which their Lutheran counterparts dealt with it.

\title{
Lutheran Orthodoxy
}

In comparison with Reformed orthodox theologians, Lutheran Orthodox theologians have similar concerns, and in the broader picture, have similar doctrines of justification. Both groups believe that justification is by faith alone, by God's grace alone, and that it rests upon the imputed righteousness of Christ, which consists in his active and passive obedience (Kolb and Wengert 2000: 494-97). Evidence of the agreement on these points comes from the harmony of Reformed confessions compiled under the oversight of Theodore Beza (1519-1605). Beza included a number of Lutheran confessional documents and their respective statements on justification to show the Reformed agreement with the Lutheran churches on this key doctrine of the Reformation (Beza 1586: 242-305; Beza 1592). Yet, this does not mean that there was perfect agreement regarding the doctrine of justification, particularly as it related to other doctrines. 
The Formula of Concord (1577) famously rejects the Reformed doctrine of predestination (Kolb and Wengert 2000: 517-20, 640-56; cf. Arand, Kolb, and Nestingen 2012: 201-16). Lutheran theologians generally do not link their doctrine of justification to the decree in the same manner as the Reformed. Another key difference between the two groups is the doctrine of the covenant. Generally, as a rule, Lutheran theologians do not give the doctrine of the covenant the same architectonic function as the Reformed, though there are exceptions (Jäger 1713). Like the Reformed, Lutheran theologians were eager to protect the extra nos of justification. But Lutheran Orthodox theologians employed different theological distinctions to preserve this characteristic.

One Lutheran theologian, Sebastian Schmidt (1617-96), specifically engages the Reformed orthodox theologians, such as Maccovius and Wendelin, on the active-passive distinction. Schmidt rejects the distinction because, in his analysis, Maccovius and Wendelin treat active justification as an immanent act whereas he believes it is a transient act of God. In his judgment Maccovius confuses justification with predestination (Schmidt 1696: VI.iv-viii). Moreover, he believed that the distinction ultimately rested upon the erroneous Reformed doctrine of absolute predestination (1696: VI.ix). Schmidt contends that there is only one type of justification, which is a temporal and transient act (Schmidt 1696: VI.ix). Given the Lutheran rejection of the Reformed doctrine of predestination, especially the proclamations of the Synod of Dordt (1618-19), Schmidt's comments reflect the general approach of Lutheran theologians regarding the doctrines of justification and imputation (Hunnius 1663).

Lutheran theologians were concerned with the same doctrinal errors as the Reformed, and hence engaged Roman Catholics, Osiander, Arminians, and Socinians in their treatments of justification (Quenstedt 1691: 528-78). To defend the extra nos of imputed righteousness, Johannes Quenstedt (161788 ) states that the effects of justification are mystical union with God, adoption, peace of conscience, certainty in prayer, sanctification, and eternal life (Quenstedt 1691: 526). In contrast to Osiander, who placed justification in union with Christ, Quenstedt places justification first and union with Christ as an effect. Quenstedt further emphasizes this point in his definition of justification when he explains that justification is an external act of the sacred Trinity. Imputation brings the alien righteousness of Christ, which believers apprehend by faith (Quenstedt 1691: 526). But though Quenstedt placed justification prior to union with Christ and set them in a cause-and-effect relationship, this does not mean that he believed that God parceled redemption in a chronological piecemeal approach, step by step.

Quenstedt clearly affirms the simultaneity of redemption: 'Regeneration, justification, union, and renovation are simultaneous, and, being more 
closely united than the ingredients of an atom (quovis puncto mathematico arctiores), so cohere that they cannot be separated or rent asunder' (Quenstedt 1691; 621; Schmid 1899: 481). So for Quenstedt, believers receive all of the benefits of union with Christ simultaneously. But Quenstedt makes the following qualification: 'Yet, according to our mode of conceiving them, justification and regeneration are prior in order to the mystical union' (Quenstedt 1691: 621). Quenstedt clearly places justification prior to union, an emphasis most likely developed in response to the Osiander controversy-the righteousness of justification stands outside of the believer not within him. But how do Lutheran Orthodox theologians account for this seemingly contradictory assertion that the benefits are simultaneously applied, yet justification precedes union with Christ?

The key to untangling this apparent Gordian knot appears in the works of other Lutheran theologians, such as David Hollatz (1648-1713). Hollatz writes: 'Although the mystical union by which God dwells in the soul as in a temple, may, according to our mode of conception, follow justification in the order of nature [ordine naturae], it is however to be acknowledged that the formal union of faith, by which Christ is apprehended, put on, and united with us, as the mediator and the author of grace and pardon, logically precedes justification' (Hollatz 1763: 933; Schmid 1899: 481). Hollatz employs the order of nature to prioritize the various elements of redemption. But whence does this term arise and how does it function? The term ordo naturae originates with the theology of John Duns Scotus (ca. 1266-1308) and the medieval debates over future contingents. In contrast to Thomas Aquinas (1225-74), who employed a Boethian model of God's relationship to eternity where past, present, and future are all equally present to God, Duns Scotus instead posited the idea that there are non-temporal, logical 'moments' or instantes naturae ('instants of nature'). Time is a human construct, something that does not bind God (Gelber 2004: 130-34; Normore 1984: 359-81, esp. 367-69). This concept allowed theologians to prioritize various elements in their theological discussions about God without being concerned about the chronological or temporal sequence.

As the Reformation progressed and Reformed and Lutheran theologians employed medieval scholastic concepts and distinctions in their theology, they discovered Scotus's instantia naturae, or the ordo naturae ('order of nature'). Reformed orthodox theologians employed the concept of the ordo naturae to:

- Explain the order of the trinitarian processions (Owen 1674: 162)

- Delineate the order and priority of the eternal decrees (Gillespie 1677: 54, 55, 79, 80, 376; Goodwin 1681: 60, 62)

- Relate the different elements of the ordo salutis, i.e., which comes first, faith or repentance (Goodwin 1692: 16; Ames 1968: I.ii.5)?

PERICHORESIS 14.3 (2016) 
Lutheran theologians, such as Hollatz, employed this concept to prioritize the simultaneously received benefits of redemption. Reformed theologians likewise did the same, though in different ways.

Francis Roberts (1609-75), author of the massive Mystery and Marrow of the Bible (1675), for example, explains that there are two distinct and inseparable branches of justification: the remission of sins and the imputation of Christ's righteousness. But he nevertheless stipulates: 'In Order of Nature, Acceptation of our persons as righteous, for Christs imputed righteousness, goes before the Remission of our sins in Christ, and is as the cause thereof: for Christs righteousness actually imputed to us, as the matter of our righteousness, is the foundation of our Remission' (Roberts 1657: 1477). John Owen makes a similar observation concerning the priority of imputation in redemption. He seeks to answer the question: in what way does Christ's imputed righteousness belong to the elect prior to their justification (Owen 1677: 232)? Owen invokes the Scotist concept to explain in what sense imputation is antecedent to justification. He argues that in order for someone to be justified, they must have a perfect righteousness by which to secure right and title to eternal life; such a righteousness must be 'in order of nature antecedently unto their Justification' (Owen 1677: 233).

Owen argues that given Christ's appointment as covenant surety within the covenant of redemption, God imputes the sin of the elect unto Christ, moreover the elect have right to Christ's righteousness given their election in him (Owen 1677: 251, 253). So Christ's forensic work and appointment precedes a person's actual justification. Only when a person professes faith in Christ does he enter into union with the messiah and thus actually lay hold of Christ's imputed righteousness. Owen writes: 'The imputation of sin unto Christ was antecedent unto any real union between him and sinners, whereon he took their sin on him'. But then Owen stipulates, 'But the imputation of his Righteousness unto Believers, is consequential in order of nature unto their union with him, whereby it becomes theirs in a peculiar manner' (Owen 1677: 511-12).

The differences between Owen on the one hand and Quenstedt and Hollatz on the other are evident, which is illustrated in their differing orders:

\section{Owen}

1. Election in Christ with imputation of sin to Christ and his antecedent righteousness as surety in the covenant of redemption

2. Actual Union with Christ

\section{Quenstedt and Hollatz}

1. Justification

2. Regeneration-Calling

3. Faith

4. Union 
3. Faith

4. Imputation

These theologians clearly have different sequences, but three similarities should be noted. First, this is not a temporal order-all three couch their respective orders as non-temporal and logical, according to the ordo naturae. Second, they affirm the simultaneity of the application of redemption. Third, they protect the extra nos of justification but do so through different means. All three were concerned to protect the extra nos of justification, but for slightly different reasons. The Lutherans wanted to address Osiander's erroneous views, and Owen was specifically concerned about Roman Catholicism and Neonomianism (Owen 1677: 191, 241). But they accomplished this by different means: Owen and the Reformed typically appealed to the decree nestled in the doctrine of the pactum and to the active-passive justification distinction, whereas the Lutherans instead argued for a different logical prioritization of the application of redemption. Despite the differences, in both formulations imputation in some sense stands outside of union with Christ, though for Owen and the Reformed the ultimate reception of imputation was dependent upon the Christ's mystical union with the believer. For the Reformed imputation exists in the decree and covenant of redemption and for the Lutherans it logically precedes union with Christ in the ordo naturae.

\section{Conclusion}

This essay is a brief examination of a very common yet little-researched Reformed orthodox distinction. Further research should be undertaken to determine its precise origins and the varied ways in which it has been employed in Reformed orthodox systems. The existence and use of the distinction demonstrates that the Reformed were just as eager as the Lutherans to protect the extra nos of Christ's imputed righteousness-justification does not rest upon infused righteousness or the essential righteousness of Christ as shared in the union, and neither does it rest upon the believer's good works or his faith. Through the active-passive distinction Reformed theologians clearly distinguished between impetrated and applied righteousness. In this respect, Herman Bavinck (1854-1921) notes that not one Reformed theologian 'treated or completed the doctrine of justification in the locus of the counsel of God or the covenant of redemption, but they all brought it up in the order of salvation, sometimes as active justification before and as passive justification after faith'. They did this, argues Bavinck, to protect the legal foundation of redemption-that it lies with the triune God and in Christ's righteousness, not with humanity (Bavinck 2003-08: III:591). In this unique manner Reformed orthodox theologians maintained the doctrine of union with Christ but also preserved the extra nos of his imputed righteousness.

PERICHORESIS 14.3 (2016) 


\section{Bibliography}

Á Brakel W (1993) The Christian's Reasonable Service, 4 volumes. Morgan, PA: Soli Deo Gloria.

Ames W (1630) Medulla S. S. Theologiae. London: Robert Allot.

Ames W (1968) The Marrow of Theology. Eusden J (trans). Grand Rapids, MI: Baker.

Arand C, Kolb R, and Nestingen J, eds (2012) The Lutheran Confessions. History and Theology of 'The Book of Concord'. Minneapolis, MN: Fortress.

Bavinck H (2003-08) Reformed Dogmatics, 4 volumes. Bolt J (ed), Vriend J (trans). Grand Rapids, MI: Baker.

Beeke J and Jones M (2012) A Puritan Theology. Doctrine for Life. Grand Rapids, MI: Reformation Heritage Books.

Bellarmine R (1610) De Iustificatione, in Disputationum Roberti Bellarmini, volume 3: De Controversiis Christianae Fidei. Leiden: Ioannes Pillehotte.

Berkhof L (1996) Systematic Theology, New Combined Edition. 1932, 1938; Grand Rapids, MI: Eerdmans.

Beza T, ed (1586) An Harmony of the Confessions of the Faith of the Christian and Reformed Churches. Cambridge: Thomas Thomas.

Beza T (1592) Apologia Pro Iustificatione Per Unius Christi Viva Fide Apprehensi Iustitiam Gratis Imputatam. Geneva: Oannes le Preux.

Boersma H (2004) A Hot Pepper Corn. Richard Baxter's Doctrine of Justification in Its Seventeenth-Century Context of Controversy. Vancouver: Regent College Publishing.

Brown of Wamphray J (1695) The Life of Justification Opened. Utrecht.

Calvin J (1559) Institutio Christianae Religionis. Geneva: Robert Stephanus.

Calvin J (1960) Institutes of the Christian Religion. Battles F (trans). Grand Rapids, MI: Eerdmans.

Calvin J (2009) Canons and Decrees of the Council of Trent, with the Antidote, 1547. In John Calvin: Tracts and Letters. Volume 3. Beveridge H, ed (1844). Edinburgh: Banner of Truth.

Fesko J (2012) Beyond Calvin. Union with Christ and Justification in Early Modern Reformed Theology (1517-1700). Göttingen: Vandenhoeck \& Ruprecht.

Fesko J (2014) Arminius on Justification. Reformed or Protestant? Church History and Religious Culture 94(1): 1-21.

Fesko J (2015) The Covenant of Redemption. Origins, Development, and Reception Göttingen: Vandenhoeck \& Ruprecht.

Fichter J (1944) James Layñez-Jesuit. St. Louis: Herder Book Company.

Gelber H (2004) It Could Have Been Otherwise. Contingency and Necessity in Dominican Theology at Oxford, 1300-1350. Leiden: Brill.

Gillespie P (1677) The Ark of the Covenant Opened. London: Tho. Parkhurst. 
JOHN V. FESKO

Goodwin T (1681) An Exposition on the First, and Part of the Second Chapter, of the Epistle to the Ephesians. London: T. G.

Goodwin T (1692) Man's Restauration by Grace. London: Thomas Goodwin.

Goudriaan A (2010) Justification by Faith and the Early Arminian Controversy. In Wisse M, Sarot M, and Otten W (eds) Scholasticism Reformed. Essays in Honour of Willem J. van Asselt. Leiden: Brill.

Heidegger J (1690) Tumulus Tridentini Concilii. Zurich: David Gessnerus.

Hollatz D (1763) Examen Theologicum Acromaticum Universam Theologiam. Leipzig: Breitkopfius et Fil.

Hunnius N (1663) Diaskepsis Theologica De fundamentali Dissensu Doctrinae Evangelicae-Lutheranae, et Calvinianae, seu Reformatae. Cum Praemia Consideratione Hypokriseos Calvinianae, Dordrechtana Synodo Proditae. Wittenberg: Fincelius.

Jäger J (1713) Pactum Patris ac Filii Aeternum, Tanquam Fundamentum Foederis Gratia, en Synopsis. Tuebingen: Reisius.

Jones M (2010) Why Heaven Kissed Earth. The Christology of the Puritan Reformed Orthodox Theologian, Thomas Goodwin (1600-80). Göttingen: Vandenhoeck \& Ruprecht.

Kolb R and Wengert T, eds (2000) The Book of Concord: The Confessions of the Evangelical Lutheran Church. Minneapolis, MI: Fortress, 2000.

Layñez D (1886) Disputatio de justitia imputata. In Hartmannus Grisar (ed) Jacobi Lainez 'Disputationes Tridentiae', volume 2. Regensburg: Feliciani Rauch.

Luther M (1957) The Freedom of the Christian, in Luther's Works, volume 31. Minneapolis, MI: Fortress.

Maccovius J (1656) Distinctiones et Regulae Theologicae ac Philosophicae. Oxford: Robert Blagravius.

Marckius J (1749) Compendium Theologiae Christianae Didactico-Elencticum. Amsterdam: Adrian Douci \& Abr. A Paddenburg.

Maresius S (1659) Collegium Theologicume. Groningen: Franciscus Bronchorstius.

Mattes M (2014) Luther on Justification as Forensic and Effective. In Kolb R, Dingel I, and Batka L (eds) The Oxford Handbook of Martin Luther's Theology. Oxford: Oxford University Press.

Maxcey C (1979) Double Justice, Diego Layñez, and the Council of Trent, Church History 48(3): 269-278.

Melanchthon P (2002) Confutation of Osiander (Sept 1555). In Lund E (ed) Documents from the History of Lutheranism 1517-1750. Minneapolis, MI: Fortress, 2002

Melanchthon P (1841) No. 5848: Iudicium de Osiandro. In Bretschneider C (ed) Corpus Reformatorum, volume 8. Halle: C. A. Schwetschke et Filium, 1841 .

PERICHORESIS 14.3 (2016) 
Muller R (1985) Dictionary of Latin and Greek Theological Terms: Drawn Principally from Protestant Scholastic Theology. Grand Rapids, MI: Baker Books.

Muller R (2007) Toward the Pactum Salutis: Locating the Origins of a Concept. Mid-America Journal of Theology 18(n.i.): 11-65.

Normore C (1984) Future Contingents. In Kretzman N, Kenny A, and Pinborg J (eds) The Cambridge History of Later Medieval Philosophy. From the Rediscovery of Aristotle to the Disintegration of Scholasticism 1100-1600. Cambridge: Cambridge University Press.

O’Malley J (2013) Trent. What Happened at the Council. Cambridge: Belknap Press.

Oberman H (1992) The Dawn of the Reformation. Essays in Late Medieval and Early Reformation Thought. Grand Rapids, MI: Eerdmans.

Osiander A (1994) Disputatio de Iustificatione in Gesamtausgabe, volume 9. Güttersloher Verlagshaus.

Owen J (1674) Pneumatologia. Or a Discourse Concerning the Holy Spirit. London: Nathaniel Ponder.

Owen J (1677) Justification by Faith Through the Imputation of the Righteousness of Christ, Explained, Confirmed, E Vindicated. London: R. Boulster.

Quenstedt J (1691) Theologia Didactico-Polemica, Sive, Systema Theologicum. Wittenberg: Johannes Ludolphus Quenstedt.

Rijssen L (1695) Francisci Turretini S. S. Theologiae Doctoris \& Professoris Compendium Theologiae Didactico-Elencticae. Amsterdam: Georgius Gallet.

Roberts F (1657) Medulla Bibliorum. The Mysterie and Marrow of the Bible. London: George Calvert.

Rutherford S (1636) Exercitationes Apologeticae Pro Divina Gratia. Amsterdam: Henricus Laurentius.

Savoy (1659) A Declaration of the Faith and Order Practiced in the Congregational Churches In England. London: John Field.

Schmid H (1899) The Doctrinal Theology of the Evangelical Lutheran Church. Hay $\mathrm{C}$ and Jacobs H (trans). Philadelphia: Lutheran Publication Society.

Schmidt S (1696) Articulorum Formulae Concordiae Repetitio. Strasbourg: Josias Staedelius.

Tipton L (2013) Biblical Theology and the Westminster Standards Revisited. Union with Christ and Justification Sola Fide. Westminster Theological Journal 75(1): 1-12.

Trelcatius L (1604) Scholastica E Methodica Locorum Communium S. Theologiae Institutio. Leiden.

Trelcatius L (1610) A Briefe Institution of the Common Places of Sacred Divinity. London: Francis Burton.

Tuckney A (1679) Praelectiones Theologicae. Amsterdam: Stephani Swart. Turretin F (1992-97) Institutes of Elenctic Theology. Philipsburg, NJ: P \& R. 
Twisse W (1632) Vindicia Gratiae Potestatis ac Providentiae Dei. Amsterdam: John Jansonius.

Van Dixhoorn C (2009) The Strange Silence of Prolocutor Twisse. Predestination and Politics in the Westminster Assembly's Debate over Justification. Sixteenth Century Journal 40(2): 395-418.

Wengert T (2012) Defending the Faith: Lutheran Responses to Andreas Osiander's Doctrine of Justification, 1551-1559. Tübingen: Mohr Siebeck.

Wengert T (2013) Philip Melanchthon and John Calvin against Andreas Osiander. Coming to Terms with Forensic Justification. In Holder R (ed) Calvin and Luther. The Continuing Relationship. Göttingen: Vandenhoeck \& Ruprecht.

Westminster (1648) The Humble Advice of the Assembly of Divines, Now By Authority of Parliament Sitting At Westminster, Concerning a Confession of Faith. London.

Witsius H (1990) Economy of the Covenants between God and Man, 2 volumes. Escondido: Den Dulk Foundation.

Wittich C (1675) Theologia Pacifica. Leiden: Arnoldus Doude.

Wollebius J (1633) Christianae Theologiae Compendium. Basel: J. J. Genath.

Wollebius J (1965) Compendium Theologiae Christianae. In Beardslee J (trans) Reformed Dogmatics. New York, NY: Oxford University Press.

Zanchi G (1590) De Natura Dei Seu De Divinis Attributis, Libri V. Neustadt: Matthaeus Harnisius. 